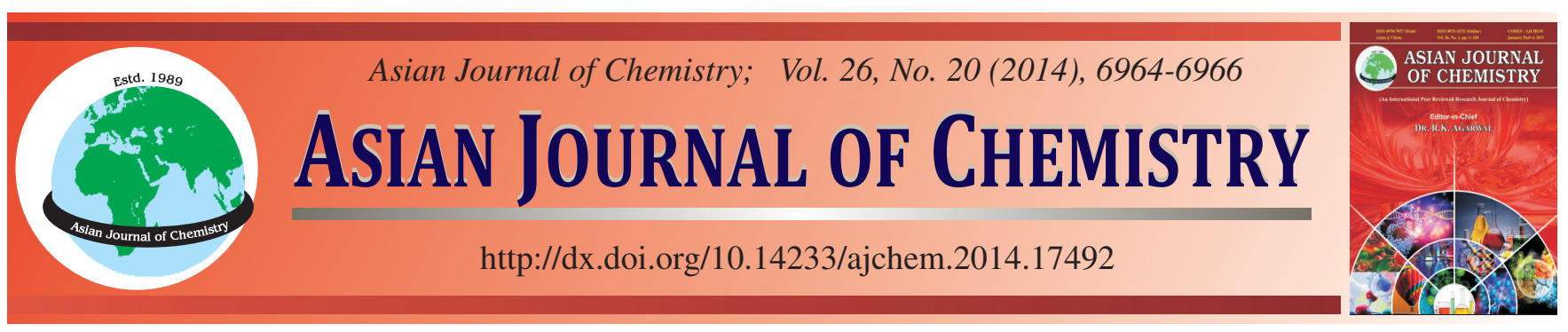

\title{
Synthesis and Characterization of Five Bisoxime-Type Chelating Ligands Based on Bis(aminooxy)alkane and 2-Naphthaldehyde
}

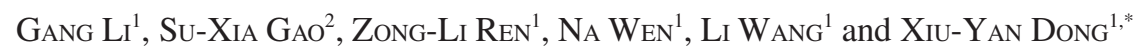

${ }^{1}$ School of Chemical and Biological Engineering, Lanzhou Jiaotong University, Lanzhou 730070, P.R. China

${ }^{2}$ School of Environmental and Municipal Engineering, Lanzhou Jiaotong University, Lanzhou 730070, P.R. China

*Corresponding author: E-mail: dxy568@163.com

Received: 1 March 2014;

Accepted: 5 May 2014;

Published online: 25 September 2014;

AJC-16048

Five bisoxime chelating ligands $\mathbf{L}^{1}-\mathbf{L}^{\mathbf{5}}$ have been synthesized from 2-naphthaldehyde and 1,2-bis(aminooxy)ethane, 1,3-bis(aminooxy)propane, 1,4-bis(aminooxy)butane, 1,5-bis(aminooxy)pentane and 1,6-bis(aminooxy)hexane in hot ethanolic medium, respectively and characterized by elemental analyses, IR, UV-visible spectra and ${ }^{1} \mathrm{H}$ NMR spectroscopy. The bisoxime chelating ligands $\mathbf{L}^{1}-\mathbf{L}^{5}$ may be promising units for the construction of supramolecular metal complexes.

Keywords: Bisoxime chelating ligand, Synthesis, Characterization.

\section{INTRODUCTION}

In recent year, several workers have produced a large number of oxime-type ligand ${ }^{1}$. Oxime, which is a sort of Schiff base ligands, has strong coordination ability and biological activity $^{2}$. Most of the transition metal oxime complexes have bactericida $1^{3}$, insecticidal ${ }^{4}$ and detoxificating biological functions $\mathrm{s}^{2,5}$.

Bisoxime compounds have long been used as organic chelating ligands, because bisoxime complexes offer both high reactivity and selectivity include epoxidation of olefins, asymmetric ring-opening of epoxides, olefin aziridination, olefin cyclopropanation and formation of cyclic, linear polycarbonates $^{6}$ and building blocks for cyclic supramolecular structures ${ }^{7}$. The large electronegativity of oxygen atoms affect strongly the electronic properties of $\mathrm{N}_{2} \mathrm{O}_{2}$ coordination sphere, which can lead to different and novel properties and structures of the resulted complexes. Thus, we have recently studied some novel bisoxime chelating compounds on the basis of $O$-alkyloxime instead of the imine moiety ${ }^{8,9}$. Herein, we report on the synhesis and characterization of five bisoximes compounds, 2,2'-[(ethane-1,2-diyldioxy)bis(nitrilomethylidyne)]dinaphthalene, 2,2'-[(propane-1,3-diyldioxy)bis(nitrilomethylidyne)]dinaphthalene, 2,2'-[(butane-1,4-diyldioxy)bis(nitrilomethylidyne)]dinaphthalene, 2,2'-[(pentane-1,5-diyldioxy) bis(nitrilomethylidyne)]dinaphthalene and 2,2'-[(hexane-1,6diyldioxy)bis(nitrilomethylidyne)]dinaphthalene.

\section{EXPERIMENTAL}

2-Naphthaldehyde, 1,2-dibromoethane, 1,3-dibromopropane, 1,4-dibromobutane, 1,5-dibromopentane and 1,6- dibromohexane were purchased and used without further purification. The other reagents and solvents were analytical grade reagents from Tianjin Chemical Reagent Factory. The others are the same as literature ${ }^{8,10}$.

General procedure: Synthetic route to bisoxime chelating ligands $\mathbf{L}^{\mathbf{1}}-\mathbf{L}^{\mathbf{5}}$ are shown in Fig. 1. 1,2-bis(aminooxy)ethane, 1,3-bis(aminooxy)propane, 1,4-bis(aminooxy)butane, 1,5bis(aminooxy)pentane and 1,6-bis(aminooxy)hexane were synthesized according to an analogous method reported earlier ${ }^{10}$.

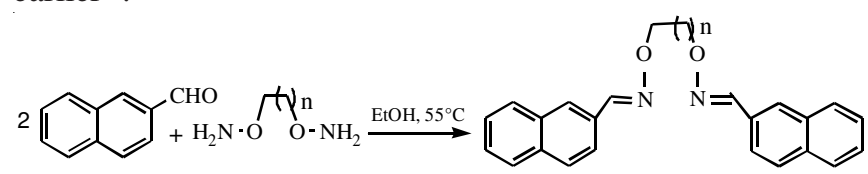

Fig. 1. Synthetic route to bisoxime chelating ligands $\mathbf{L}^{1}-\mathbf{L}^{5}$. $\mathbf{L}^{1}: \mathbf{n}=1 ; \mathbf{L}^{2}$ : $\mathrm{n}=2 ; \mathbf{L}^{3}: \mathrm{n}=3 ; \mathbf{L}^{4}: \mathrm{n}=4 ; \mathbf{L}^{5}: \mathrm{n}=5$

Preparation of 2,2'-[(ethane-1,2-diyldioxy)bis(nitrilomethylidyne)]dinaphthalene $\left(\mathbf{L}^{1}\right)$ : To an ethanolic solution (8 mL) of 2-naphthaldehyde (356.6 mg, $2.28 \mathrm{mmol}$ ) was added an ethanolic solution (5 mL) of 1,2-bis(aminooxy)ethane (105.7 mg, $1.14 \mathrm{mmol}$ ). After the solution had been stirred at $55^{\circ} \mathrm{C}$ for $4 \mathrm{~h}$, the white precipitate was filtered, washed successively with ethanol and $n$-hexane, respectively. The product was dried under reduced pressure and purified with recrystallization from ethanol to yield white powder-like compound $\mathbf{L}^{\mathbf{1}}$.

Preparation of 2,2'-[(propane-1,2-diyldioxy)bis(nitrilomethylidyne)]dinaphthalene $\left(\mathbf{L}^{2}\right)$ : To a hot ethanolic solution (8 mL) of 2-naphthaldehyde (368.3 mg, $2.40 \mathrm{mmol}$ ) was added an ethanolic solution (5 mL) of 1,3-bis(aminooxy)propane 
$(167.8 \mathrm{mg}, 1.20 \mathrm{mmol})$. After the solution had been stirred at $55^{\circ} \mathrm{C}$ for $4 \mathrm{~h}$, then cooled to room temperature, the white precipitate was filtered and washed successively with ethanol and $n$-hexane, respectively. The product was purified with recrystallization from ethanol $/ n$-hexane and dried under vacuum to obtain white powder-like compound $\mathbf{L}^{2}$.

Preparation of 2,2'-[(butane-1,2-diyldioxy)bis(nitrilomethylidyne)]dinaphthalene $\left(\mathbf{L}^{3}\right)$ : To a hot ethanolic solution (8 mL) of 2-naphthaldehyde (342.4 mg, $2.20 \mathrm{mmol}$ ) was added an ethanolic solution ( $5 \mathrm{~mL}$ ) of 1,4-bis(aminooxy)butane $(157.6 \mathrm{mg}, 1.10 \mathrm{mmol})$. After the solution had been stirred at $55^{\circ} \mathrm{C}$ for $6 \mathrm{~h}$, then cooled to room temperature, the white precipitate was filtered and washed successively with ethanol and $n$-hexane, respectively. The product was purified with recrystallization from ethanol $/ n$-hexane and dried under vacuum to obtain white powder-like compound $\mathbf{L}^{3}$.

Preparation of 2,2'-[(pentane-1,2-diyldioxy)bis (nitrilomethylidyne)]dinaphthalene $\left(\mathbf{L}^{4}\right)$ : To a hot ethanolic solution $(8 \mathrm{~mL})$ of 2-naphthaldehyde $(203.6 \mathrm{mg}, 1.30 \mathrm{mmol})$ was added an ethanolic solution (5 mL) of 1,5-bis(aminooxy)pentane ( $121.8 \mathrm{mg}, 0.60 \mathrm{mmol})$. After the solution had been stirred at $55{ }^{\circ} \mathrm{C}$ for $4 \mathrm{~h}$, then cooled to room temperature, the white precipitate was filtered and washed successively with ethanol and $n$-hexane, respectively. The product was purified with recrystallization from ethanol $/ n$-hexane and dried under vacuum to obtain white powder-like compound $\mathbf{L}^{4}$.

Preparation of 2,2'-[(hexane-1,2-diyldioxy)bis(nitrilomethylidyne)]dinaphthalene $\left(\mathbf{L}^{\mathbf{5}}\right)$ : To a hot ethanolic solution $(8 \mathrm{~mL})$ of 2-naphthaldehyde (358.2 $\mathrm{mg}, 2.30 \mathrm{mmol}$ ) was added an ethanolic solution $(5 \mathrm{~mL})$ of 1,6-bis(aminooxy)henane $(241.8 \mathrm{mg}, 1.20 \mathrm{mmol})$. After the solution had been stirred at $55{ }^{\circ} \mathrm{C}$ for $4 \mathrm{~h}$, then cooled to room temperature, the white precipitate was filtered and washed successively with ethanol and $n$-hexane, respectively. The product was purified with recrystallization from ethanol $/ n$-hexane and dried under vacuum to obtain white powder-like compound $\mathbf{L}^{\mathbf{5}}$.

\section{RESULTS AND DISCUSSION}

Five bisoxime chelating ligands $\mathbf{L}^{\mathbf{1}} \mathbf{-} \mathbf{L}^{\mathbf{5}}$ have been synthesized with good yields and the composition are confirmed by elemental analyses, IR, UV-visible spectra and ${ }^{1} \mathrm{H}$ NMR spectroscopy.
Physical and chemistry properties: The colour, yields, melting points and elemental analytical results of the synthesized bisoxime chelating ligands $\mathbf{L}^{1}-\mathbf{L}^{\mathbf{5}}$ are presented in Table-1.

Their compositions agree with the formulae. All the chelating ligands are stable in air and soluble in chloroform, dichloromethane, DMF and DMSO, insoluble in $n$-hexane. In addition, $\mathbf{L}^{3}, \mathbf{L}^{4}$ and $\mathbf{L}^{5}$ are soluble in methanol, but $\mathbf{L}^{1}$ and $\mathbf{L}^{2}$ are insoluble in methanol, ethanol. $\mathbf{L}^{\mathbf{1}}, \mathbf{L}^{2}$ and $\mathbf{L}^{3}$ are soluble in acetone and acetonitrile. But $\mathbf{L}^{4}$ and $\mathbf{L}^{5}$ are insoluble in acetone and acetonitrile.

IR spectra: The key IR spectral data for $\mathbf{L}^{\mathbf{1}}-\mathbf{L}^{\mathbf{5}}$ are given in Table-2. In the IR spectra of the bisoxime chelating ligands $\mathbf{L}^{1}-\mathbf{L}^{\mathbf{5}}$, the characteristic $\mathrm{C}=\mathrm{N}$ stretching bands of the bisoxime chelating ligands $\mathbf{L}^{1}-\mathbf{L}^{\mathbf{5}}$ appear at $1616-1610 \mathrm{~cm}^{-1}$, respectively ${ }^{10}$. In addition, in the $1488-1472 \mathrm{~cm}^{-1}$ region, the observed bands were attributed to naphthalene ring $\mathrm{C}=\mathrm{C}$ vibrations.

UV-visible and ${ }^{1} \mathrm{H}$ NMR spectra: The UV-visible spectra of the bisoxime chelating ligands $\mathbf{L}^{1}-\mathbf{L}^{5}$ in $5 \times 10^{-5} \mathrm{~mol} \times \mathrm{L}^{-1}$ dichloromethane solution are presented in Table-3. The bisoxime chelating ligands $\mathbf{L}^{\mathbf{1}}-\mathbf{L}^{\mathbf{5}}$ exhibit two intense peaks at around 270 and $325 \mathrm{~nm}$. The former absorption peaks at about $270 \mathrm{~nm}$ can be assigned to the $\pi-\pi *$ transition of the naphthalene rings, while the latters can be attributed to the intra-ligand $\pi-\pi^{*}$ transition of the $\mathrm{C}=\mathrm{N}$ bonds ${ }^{11}$. It is of note that there was no absorption around $400 \mathrm{~nm}$, which is seen in the corresponding Salen derivatives. The absorption is ascribed to the quinoid form of $\mathrm{H}_{2} \mathrm{salen}^{11}$.

The ${ }^{1} \mathrm{H}$ NMR spectra of the bisoxime chelating ligands $\mathbf{L}^{1}-\mathbf{L}^{5}$ in DMSO- $d_{6}$ are shown in Table-3. The ${ }^{1} \mathrm{H}$ NMR spectra showed a singlet at about 8.28-8.44 ppm indicating the existence of oxime bonds ${ }^{11}$.

\section{Conclusion}

Five new bisoxime chelating ligands $\mathbf{L}^{1}-\mathbf{L}^{\mathbf{5}}$ that have two oxime bonds instead of imine bonds have been designed and synthesized by the reaction of 2 equivalents of 2-naphthaldehyde with 1,2-bis(aminooxy)ethane, 1,3-bis(aminooxy)propane, 1,4-bis(aminooxy)butane, 1,5-bis(aminooxy)pentane and 1,6-bis(aminooxy)hexane in hot ethanolic medium, respectively. The characterizations of the bisoxime chelating ligands

TABLE-1

COLOUR, YIELDS, MELTING POINTS AND ANALYTICAL DATA OF BISOXIME CHELATING LIGANDS $\mathbf{L}^{\mathbf{1}}-\mathbf{L}^{\mathbf{5}}$

\begin{tabular}{cccccccc}
\hline \multirow{2}{*}{ Compound } & \multirow{2}{*}{ Colour } & \multirow{2}{*}{ m.p. $\left({ }^{\circ} \mathrm{C}\right)$} & \multirow{2}{*}{ Yield $(\%)$} & m.f. (m.w.) & \multicolumn{2}{c}{ Elemental analysis (\%): Found (Calcd.) } \\
\cline { 6 - 8 } & & & & $\mathrm{C}$ & $\mathrm{H}$ & $\mathrm{N}$ \\
\hline $\mathbf{L}^{\mathbf{1}}$ & White & $153-154$ & 72.1 & $\mathrm{C}_{24} \mathrm{H}_{20} \mathrm{~N}_{2} \mathrm{O}_{2}(368.43)$ & $78.38(78.24)$ & $5.41(5.47)$ & $7.68(7.60)$ \\
$\mathbf{L}^{2}$ & White & $139-140$ & 69.2 & $\mathrm{C}_{25} \mathrm{H}_{22} \mathrm{~N}_{2} \mathrm{O}_{2}(382.43)$ & $78.59(78.51)$ & $5.83(5.80)$ & $7.30(7.32)$ \\
$\mathbf{L}^{3}$ & White & $127-128$ & 71.2 & $\mathrm{C}_{26} \mathrm{H}_{24} \mathrm{~N}_{2} \mathrm{O}_{2}(396.41)$ & $78.71(78.76)$ & $6.07(6.10)$ & $7.09(7.07)$ \\
$\mathbf{L}^{4}$ & White & $115-116$ & 65.2 & $\mathrm{C}_{27} \mathrm{H}_{26} \mathrm{~N}_{2} \mathrm{O}_{2}(410.58)$ & $79.08(79.00)$ & $6.31(6.38)$ & $6.85(6.82)$ \\
$\mathbf{L}^{5}$ & White & $102-103$ & 64.5 & $\mathrm{C}_{28} \mathrm{H}_{28} \mathrm{~N}_{2} \mathrm{O}_{2}(424.51)$ & $79.26(79.22)$ & $6.61(6.65)$ & $6.68(6.60)$ \\
\hline
\end{tabular}

TABLE-2

KEY IR BANDS $\left(\mathrm{cm}^{-1}\right)$ FOR THE SYNTHESIZED BISOXIME CHELATING LIGANDS $\mathbf{L}^{1}-\mathbf{L}^{5}$

\begin{tabular}{cccc}
\hline Compound & $v\left(\mathrm{CH}_{\text {arom }}\right)$ & $v\left(\mathrm{CH}_{2}\right)$ & $v(\mathrm{C}=\mathrm{N})$ \\
\hline $\mathbf{L}^{\mathbf{1}}$ & 3045 & 2944,2888 & 1616 \\
$\mathbf{L}^{\mathbf{2}}$ & 3049 & 2933,2887 & 1612 \\
$\mathbf{L}^{\mathbf{3}}$ & 3050 & 2948,2882 & 1613 \\
$\mathbf{L}^{4}$ & 3058 & 2945,2889 & 1483 \\
$\mathbf{L}^{5}$ & 3056 & 2940,2880 & 1484 \\
\end{tabular}




\begin{tabular}{|c|c|c|}
\hline \multicolumn{3}{|r|}{$\begin{array}{c}\text { TABLE-3 } \\
\text { UV-VISIBLE SPECTRA AND }{ }^{1} \mathrm{H} \text { NMR DATA OF THE BISOXIME CHELATING LIGANDS } \mathbf{L}^{1}-\mathbf{L}^{5}\end{array}$} \\
\hline Compound & $\pi-\pi^{*}(\mathrm{~nm})$ & ${ }^{1} \mathrm{H}$ NMR $\left(400 \mathrm{MHz}\right.$, DMSO- $\left.d_{6}, \delta / \mathrm{ppm}\right)$ \\
\hline $\mathbf{L}^{1}$ & 270,325 & $\begin{array}{l}4.23\left(\mathrm{t}, J=5.0 \mathrm{~Hz}, 4 \mathrm{H}, \mathrm{CH}_{2}-\mathrm{O}\right), 6.79(\mathrm{~d}, J=8.0 \mathrm{~Hz}, 2 \mathrm{H}, \mathrm{PhH}), 6.92(\mathrm{dd}, J=7.8,1.8 \mathrm{~Hz}, 4 \mathrm{H}, \mathrm{PhH}), 7.07(\mathrm{~s}, 2 \mathrm{H}, \mathrm{PhH}), \\
7.12(\mathrm{~s}, 2 \mathrm{H}, \mathrm{PhH}), 7.25(\mathrm{~s}, 2 \mathrm{H}, \mathrm{PhH}), 7.33(\mathrm{~d}, J=8.0 \mathrm{~Hz}, 2 \mathrm{H}, \mathrm{PhH}), 8.44(\mathrm{~s}, 2 \mathrm{H}, \mathrm{N}=\mathrm{CH}) .\end{array}$ \\
\hline $\mathbf{L}^{2}$ & 269,323 & $\begin{array}{l}2.08\left(\mathrm{t}, J=4.2 \mathrm{~Hz}, 2 \mathrm{H}, \mathrm{CH}_{2}\right), 4.20\left(\mathrm{t}, J=4.6 \mathrm{~Hz}, 4 \mathrm{H}, \mathrm{CH}_{2}-\mathrm{O}\right), 6.80(\mathrm{~d}, J=8.2 \mathrm{~Hz}, 2 \mathrm{H}, \mathrm{PhH}), 6.93(\mathrm{~d}, J=7.6,1.4 \mathrm{~Hz}, \\
4 \mathrm{H}, \mathrm{PhH}), 7.05(\mathrm{~s}, 2 \mathrm{H}, \mathrm{PhH}), 7.13(\mathrm{~s}, 2 \mathrm{H}, \mathrm{PhH}), 7.22(\mathrm{~s}, 2 \mathrm{H}, \mathrm{PhH}), 7.33(\mathrm{~d}, J=8.0 \mathrm{~Hz}, 2 \mathrm{H}, \mathrm{PhH}), 8.38(\mathrm{~s}, 2 \mathrm{H}, \mathrm{N}=\mathrm{CH})\end{array}$ \\
\hline $\mathbf{L}^{3}$ & 271,323 & $\begin{array}{l}2.30\left(\mathrm{~d}, J=8.0 \mathrm{~Hz}, 4 \mathrm{H}, \mathrm{CH}_{2}\right), 4.41\left(\mathrm{~s}, 4 \mathrm{H}, \mathrm{CH}_{2}-\mathrm{O}\right), 6.81(\mathrm{~d}, J=8.0 \mathrm{~Hz}, 2 \mathrm{H}, \mathrm{PhH}), 6.96(\mathrm{~d}, J=8.2,2.4 \mathrm{~Hz}, 4 \mathrm{H}, \mathrm{PhH}), \\
7.05(\mathrm{~s}, 2 \mathrm{H}, \mathrm{PhH}), 7.10(\mathrm{~s}, 2 \mathrm{H}, \mathrm{PhH}), 7.18(\mathrm{~s}, 2 \mathrm{H}, \mathrm{PhH}), 7.38(\mathrm{~d}, J=7.0 \mathrm{~Hz}, 2 \mathrm{H}, \mathrm{PhH}), 8.28(\mathrm{~s}, 2 \mathrm{H}, \mathrm{N}=\mathrm{CH}) .\end{array}$ \\
\hline $\mathbf{L}^{4}$ & 272,326 & $\begin{array}{l}2.32\left(\mathrm{~d}, J=7.6 \mathrm{~Hz}, 6 \mathrm{H}, \mathrm{CH}_{2}\right), 4.42\left(\mathrm{~s}, 4 \mathrm{H}, \mathrm{CH}_{2}-\mathrm{O}\right), 6.80(\mathrm{~d}, J=8.0 \mathrm{~Hz}, 2 \mathrm{H}, \mathrm{PhH}), 6.97(\mathrm{~d}, J=7.8,1.8 \mathrm{~Hz}, 4 \mathrm{H}, \mathrm{PhH}), \\
7.08(\mathrm{~s}, 2 \mathrm{H}, \mathrm{PhH}), 7.18(\mathrm{~s}, 2 \mathrm{H}, \mathrm{PhH}), 7.29(\mathrm{~s}, 2 \mathrm{H}, \mathrm{PhH}), 7.37(\mathrm{~d}, J=7.0 \mathrm{~Hz}, 2 \mathrm{H}, \mathrm{PhH}), 8.31(\mathrm{~s}, 2 \mathrm{H}, \mathrm{N}=\mathrm{CH}) .\end{array}$ \\
\hline $\mathbf{L}^{5}$ & 274,325 & $\begin{array}{l}2.26\left(\mathrm{~d}, J=7.4 \mathrm{~Hz}, 8 \mathrm{H}, \mathrm{CH}_{2}\right), 4.46\left(\mathrm{~s}, 4 \mathrm{H}, \mathrm{CH}_{2}-\mathrm{O}\right), 6.83(\mathrm{~d}, J=6.8 \mathrm{~Hz}, 2 \mathrm{H}, \mathrm{PhH}), 6.98(\mathrm{~d}, J=7.0,2.2 \mathrm{~Hz}, 4 \mathrm{H}, \mathrm{PhH}), \\
7.09(\mathrm{~s}, 2 \mathrm{H}, \mathrm{PhH}), 7.17(\mathrm{~s}, 2 \mathrm{H}, \mathrm{PhH}), 7.28(\mathrm{~s}, 2 \mathrm{H}, \mathrm{PhH}), 7.39(\mathrm{~d}, J=7.4 \mathrm{~Hz}, 2 \mathrm{H}, \mathrm{PhH}), 8.30(\mathrm{~s}, 2 \mathrm{H}, \mathrm{N}=\mathrm{CH}) .\end{array}$ \\
\hline
\end{tabular}

$\mathbf{L}^{\mathbf{1}}-\mathbf{L}^{\mathbf{5}}$ have been made by elemental analysis, IR, UV-visible spectra and ${ }^{1} \mathrm{H}$ NMR spectroscopy. The bisoxime chelating ligands may be promising units for the construction of supramolecular metal complexes.

\section{ACKNOWLEDGEMENTS}

This work was supported by the Science and Technology support funds of Gansu Province (613028), which is gratefully acknowledged.

\section{REFERENCES}

1. V.V. Pavlishchuk, S.V. Kolotilov, A.W. Addison, M.J. Prushan, D. Schollmeyer, L.K. Thompson, T. Weyhermüller and E.A. Goreshnik, Dalton Trans., 1587 (2003).

2. D.T. Rosa, J.A. Krause Bauer and M.J. Baldwin, Inorg. Chem., 40, 1606 (2001).
3. J. Custot, J.L. Boucher, S. Vadon, C. Guedes, S. Dijols, M. Delaforge and D. Mansuy, J. Biol. Inorg. Chem., 1, 73 (1996).

4. B.H. Mehta and B. Nagarkoti, Asian J. Chem., 14, 103 (2002).

5. E.S. Rachaman, Y. Ashani and H. Leader, Arzneimittelforschung, 29, 875 (1979)

6. S. Yamada, Coord. Chem. Rev., 190-192, 537 (1999).

7. A.K. Sharma, F. Lloret and R. Mukherjee, Inorg. Chem., 46, 5128 (2007).

8. Z.L. Ren, W.K. Dong, W.J. Bai, X.N. He and L. Wang, Acta Crystallogr., E64, o1678 (2008)

9. X.Y. Dong, Y.X. Sun, L. Wang and L. Li, J. Chem. Res., 36, 387 (2012).

10. (a) W.K. Dong, Y.X. Sun, X.Y. Dong, S.J. Xing and L. Wang, J. Coord. Chem., 66, 3291 (2013); (b) W.K. Dong, L.S. Zhang, Y.X. Sun, M.M. Zhao, G. Li and X.Y. Dong, Spectrochim. Acta A, 121, 324 (2014); (c) W.-K. Dong, J. Yao and Y.X. Sun, Synth. React. Inorg. Met.-Org. NanoMet. Chem, 41, 177 (2011); (d) W.K. Dong, Y.X. Sun, C.Y. Zhao, X.Y. Dong and L. Xu, Polyhedron, 29, 2087 (2010).

11. H.E. Smith, Chem. Rev., 83, 359 (1983). 